\title{
Modern trends in the development of the construction industry in the production of building materials
}

\author{
(D)Aliya Aldungarova ${ }^{1, *}$, (D) Kapar Aryngazin1, (D) Vladimir Larichkin ${ }^{2}$, D Assem Abisheva , \\ (iD Kamilla Alibekova ${ }^{4}$ \\ ${ }^{1}$ Department of Architecture and Design, Toraighyrov University, Pavlodar, Kazakhstan \\ ${ }^{2}$ Department of Environmental Engineering Problems, Novosibirsk State Technical University, Novosibirsk, Russia \\ ${ }^{3}$ Department of Civil Engineering, L.N. Gumilyov Eurasian National University, Nur-Sultan, Kazakhstan \\ ${ }^{4}$ Department of Development and Environmental Studies, Palacký University, Olomouc, Czech Republic \\ *Correspondence: liya_1479@mail.ru
}

\begin{abstract}
The paper describes the technology of manufacturing a construction product by vibrocompression using ash and slag waste from thermal power plants in the Pavlodar region. The task of the experimental research was to obtain a hollow wall stone based on ash and slag waste with a strength grade that is not inferior to products made according to the traditional recipe. A study was carried out with selected samples of bauxite sludge from the sludge dumps of the Pavlodar Aluminum Plant, as fillers was used metallurgical slag of fractions 0-5 and 20-30 according to 6 recipes made in forms 100x100x100 $\mathrm{mm}$. The obtained samples with different ratios of components in the mixture were investigated for compressive strength, moisture absorption, frost resistance. It has been established that when ash and slag waste are added to the composition of the concrete mixture in an amount of up to $35 \%$ of the mass of dry components, the strength characteristics of the hollow wall stone correspond to the selected brand.
\end{abstract}

Keywords: slag, ash, waste, development of the construction, industry, building materials, concrete mix

\section{Introduction}

Currently, in the Republic of Kazakhstan in dumps, according to reports of independent assessments [1,2], more than 400 million tons of ash and slag waste from thermal power plants and metallurgical waste have been accumulated, which is an aggravation of the environmental situation in industrial regions and requires the development of technical solutions to improve it [3].

One of the scientific and technical solutions to this problem, which is also essential for the construction industry, is the production of construction products using industrial waste in the concrete mixture. Utilization of large-tonnage industrial waste confirms the relevance of the development of this issue and, in parallel, is strengthened by the implementation of large-scale State programs to increase the affordability of housing, mortgage lending, which ensures a stable growth in demand for construction products and, as a result, raw materials for their manufacture [4].

A promising raw material for the production of building products is ash and slag waste from thermal power plants and waste from the metallurgical industry [5,6]. In addition, today the scaling of the technology for the production of heavy concrete using ash and slag waste from thermal power plants and waste from metallurgy of the Republic of Kazakhstan is widely used [1,7].

LLP «EcostroyNII-PV», organized under the grant program «Stimulating productive innovations» from the Ministry of Education and Science of the Republic of Kazakhstan and the World Bank (Subproject № APP-SSG-17/0290F), uses ash and slag and metallurgical waste as a basis for the manufacture of building products: ash from the TPP of Pavlodar and Aksu TPP of JSC «Eurasian Energy Corporation» (EEC, ERG) based on Ekibastuz coal, slimes of the Pavlodar aluminum plant of 
JSC «Aluminum of Kazakhstan», steel-making slags of Pavlodar steel-making factories PF LLP «Casting», PF LLP «KSP Steel».

\section{Methods and Materials}

The development of new compositions of concrete mixtures with improved performance characteristics using ash and slag waste from thermal stations and metallurgical enterprises of Pavlodar region as aggregates and binder requires a large number of experiments with varying the percentage of all components that make up concrete mixtures, establishing the regularity of the effect of various additives on physical and mechanical characteristics of mixtures [8].

Expansion of the raw material base of ash and slag waste allowed us to make samples using recipes, which include ashes of the above-mentioned TPP (Table 1).

Table 1 - Chemical composition of fly ash from Pavlodar TPP-1 in \%

\begin{tabular}{llllllllll}
\hline $\mathrm{SiO}_{2}$ & $\mathrm{Al}_{2} \mathrm{O}_{3}$ & $\mathrm{TiO}_{2}$ & $\mathrm{Fe}_{2} \mathrm{O}_{3}$ & $\mathrm{CaO}$ & $\mathrm{MgO}$ & $\mathrm{K}_{2} \mathrm{O}$ & $\mathrm{Na}_{2} \mathrm{O}$ & $\mathrm{P}_{2} \mathrm{O}_{5}$ & $\mathrm{MnO}$ \\
\hline 60,6 & 28,6 & 1,4 & 5,4 & 2 & 0,5 & 0,5 & 0,2 & 0,7 & 0,1 \\
\hline
\end{tabular}

The fly ash used in our technological process (Figure 1) is characterized by a fine granular fraction $[9,10]$. According to GOST 25818-91 and 25592-91, the content of calcium oxide CaO in the ash component of the ash and slag mixture and in the fine-grained mixture should be no more than 10 $\%$ by weight. The content of magnesium oxide $\mathrm{MgO}$ in the ash component of the ash and slag mixture and in the fine-grained mixture should be no more than $5 \%$ by weight $[11,12]$. The content of sulfurous and sulfuric acid compounds in terms of SO3 in the ash and slag components of the ash-and-slag mixture should be no more than $3 \%$ by mass, including sulfide sulfur - no more than $1 \%$ by mass. The content of alkaline sodium and potassium oxides in terms of $\mathrm{Na} 2 \mathrm{O}$ in the ash component of the ash and slag mixture and in the fine-grained mixture should be no more than $3 \%$ by weight [13].

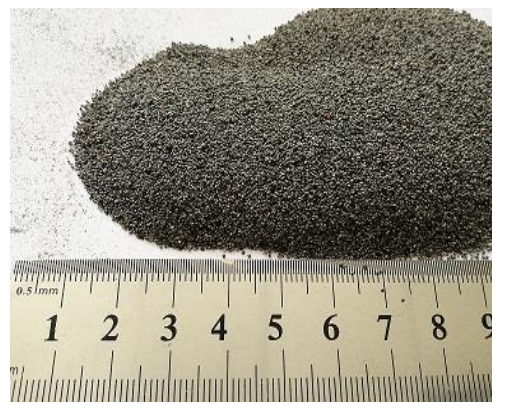

Figure 1 - Fly ash of Pavlodar TPP-1

Bauxite sludge from the Pavlodar Aluminum Plant is a by-product of the production of alumina A2O3. The currently known methods for the production of alumina can be divided into electrothermal, acidic and alkaline. It is possible to convert the alumina contained in the raw material into sodium aluminate in various ways, one of which is the «Dry» process (Bayer sintering process) or simply «Sintering» (the so-called Mueller-Jakovin process). Ore with alkali metal salts is sintered in rotary kilns, then the aluminate is leached, and the resulting aqueous solution is subjected to decomposition. The composition of the concrete mixes included bauxite sludge from the Pavlodar Aluminum Plant (Figure 2a, 2b, 2c), of various fractions, sifted into a sieve with cells from 0.05 to $2 \mathrm{~mm}$ (Table 2) [14].

Table 2-Chemical composition of bauxite sludge from Pavlodar Aluminum Plant, obtained by Bayer sintering.

\begin{tabular}{llllllll}
\hline $\mathrm{Fe}_{2} \mathrm{O}_{3}$ & $\mathrm{Al}_{2} \mathrm{O}_{3}$ & $\mathrm{CaO}$ & $\mathrm{SiO}_{2}$ & $\mathrm{TiO}$ & $\mathrm{CO}_{2}$ & $\mathrm{Na}_{2} \mathrm{O}$ & $\mathrm{MgO}$ \\
\hline $27-33$ & $4,0-5,0$ & $39-44$ & $19-21$ & 2,0 & $0,8-1,0$ & $0,9-1,5$ & $0,3-1,2$ \\
\hline
\end{tabular}


In appearance, bauxite sludge (Figure 2a) is medium-grained beige-brown sand with inclusions of easily crumbling lumps of various sizes. The moisture content of bauxite sludge samples should be within $20-30 \%$, density $-2.6-2.86 \mathrm{~g} / \mathrm{cm}^{3}$, bulk density in a loosened state - from 1.1 to $1.3 \mathrm{~g} / \mathrm{cm}^{3}$.

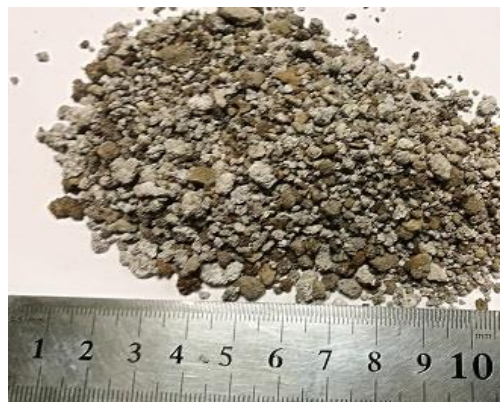

a) from the Pavlodar Aluminum Plant

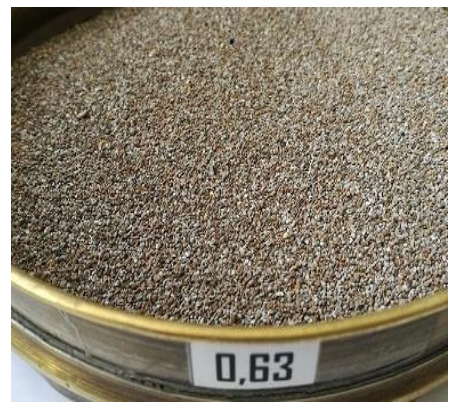

b) fraction 0.63

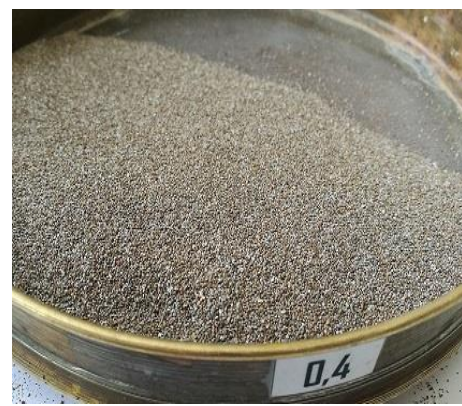

c) fraction 0.4

Figure 2-Bauxite sludge

For the research, representative samples of bauxite sludge were taken from the sludge dumps of the Pavlodar Aluminum Plant. Sludge samples were taken in accordance with the requirements GOST 12071-2014. Statistical processing of the research results was carried out in accordance with the «Recommendations for the use of bauxite slimes of alumina production in concrete and mortars» NIIZhB Gosstroy USSR 1990.

Metallurgical slag of fraction 0-5 (Figure 3a) and coarse fractions 20-30 (Figure 3b) were used as fillers.

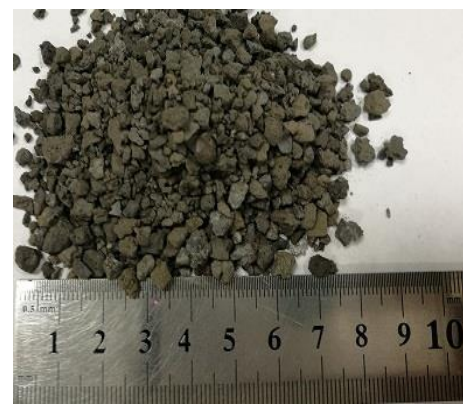

a) fraction $0-5$

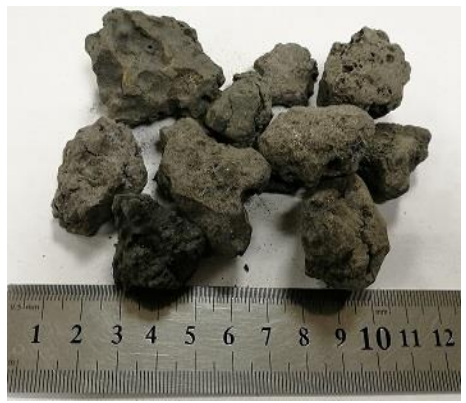

b) fraction $20-30$

Figure 3 - Metallurgical slag

The slag is gray, a porous microstructure is observed, the presence of a crystallized glassy component is noted [15-17]. Brown inclusions indicate the presence of iron oxide. The chemical composition of the slag PF LLP «Casting» (Table 3). Depending on the formulation, the abovedescribed technogenic raw materials were included in the composition of the concrete mixture as aggregates and binder [18]. For each recipe, 6 samples were made (Figure 4), which were placed in molds (Figure 5) 100x100x100 mm in accordance with GOST 25781-81, the samples (without steaming) were stored at room temperature for 28 days, after which strength tests were carried out with them (Figure 6, 7).

Table 3 - Average chemical composition of slag in EAF ESPC PF «Casting» LLP and PF «KSP steel» LLP for 2019,\%

\begin{tabular}{lllllllll}
\hline $\mathrm{Fe}_{\text {об }}$ & $\mathrm{SiO}_{2}$ & $\mathrm{Al}_{2} \mathrm{O}_{3}$ & $\mathrm{CaO}$ & $\mathrm{MgO}$ & $\mathrm{MnO}$ & $\mathrm{S}$ & осн & $\Sigma$ \\
\hline $28-$ & $12,1-$ & $1,9-$ & $21,1-$ & \multirow{2}{*}{$6,9-20,2$} & $5,1-8,2$ & $0,03-$ & $1,2-$ & $90,0-$ \\
35,9 & 18,9 & 4,8 & 24,6 & & & \\
\hline
\end{tabular}




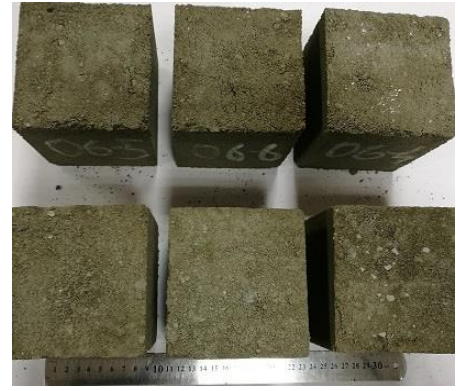

Figure $4-$ Test specimens

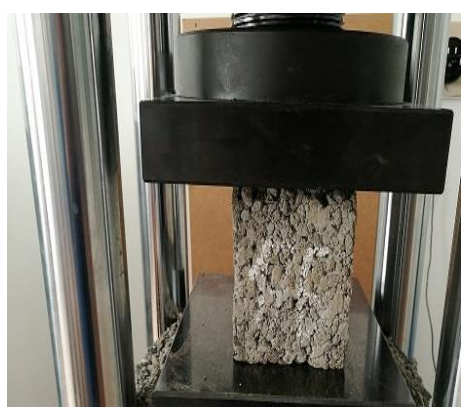

Figure 6 - Test for the strength of the sample

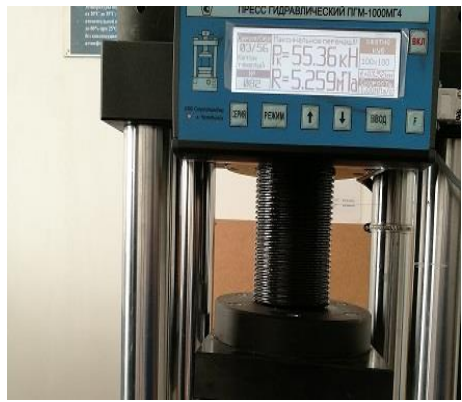

Figure 8 - Indication of strength values for sample № 17-5

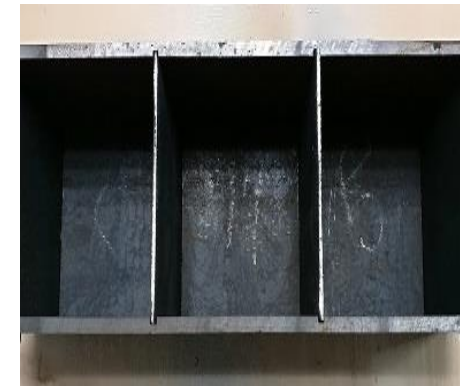

Figure 5 - Forms 100x100x100 $\mathrm{mm}$ in accordance with GOST 25781-81

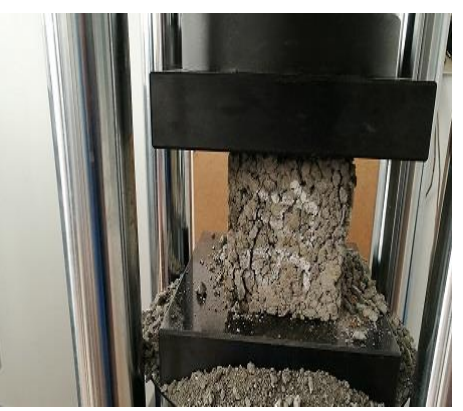

Figure 7 - Destruction of the sample

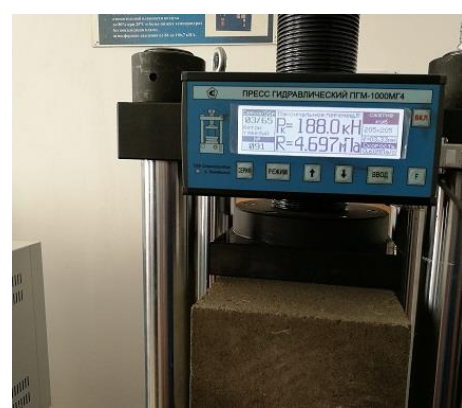

Figure 9 - Compression of a hollow wall stone

As a result of experiments, it was revealed that:

- Ashes of Pavlodar TPP, used as a filler, do not affect the decrease in the strength of the concrete mixture. Due to its low activity (when grinding ash to a size of 0,0005 ), it can be used as a replacement for clinker, which is not practical on an industrial scale. The use of ash up to $15 \%$ of the amount of cement does not affect the decrease in strength indicators and can be used as an aggregate to replace sand.

- The use of bauxite sludge with the addition of milk of lime made it possible to increase the strength of concrete specimens up to the M50 grade, class B3, 5, taking into account the absence of vibropressing. Formulation development using bauxite sludge continues.

- The use of metallurgical slag of fraction 0-5 as a filler did not affect the strength of the samples due to the absence of vibrocompression and a steaming chamber, due to which the cement adhesion process was low. At the same time, hollow stones made with metallurgical slag on the RifeyUdar-SDA production line showed class B7, 5 (M100), but the stones turned out to be heavy (27 kg).

To date, 33 recipes for concrete mixtures have been developed using various fillers, additives and binders. It should be noted that the process of vibrocompression on the Rifey-Udar-SDA line makes it possible to obtain the strength of products in a short time. For example, a sample made according to recipe № 17 received a strength almost similar to the prototype after 7 days (Figure 8 and 9). Based on the results of the tests, the compositions of concrete were selected using ash and slag waste (Table 4). 
Table 4 - Results of testing concrete samples using ash and slag waste

\begin{tabular}{|c|c|c|c|c|c|c|}
\hline $\begin{array}{c}\text { Sample } \\
\text { brand }\end{array}$ & $\begin{array}{c}\text { Mass } \\
\text { fraction of } \\
\text { cement, } \\
(\%)\end{array}$ & $\begin{array}{l}\text { Strength, } \\
\mathrm{kg} / \mathrm{cm}^{2}\end{array}$ & $\begin{array}{l}\text { Strength, } \\
\mathrm{MPa}\end{array}$ & $\begin{array}{c}\text { Concrete } \\
\text { strength } \\
\text { class }\end{array}$ & $\begin{array}{c}\text { Concrete } \\
\text { strength } \\
\text { grade }\end{array}$ & $\begin{array}{l}\text { Density, } \\
\mathrm{g} / \mathrm{cm}^{3}\end{array}$ \\
\hline Z0040-vt & 40 & 243,8 & 23,9 & $\mathrm{~B} 23$ & M300 & 2,09 \\
\hline Z1035-vt & 35 & 175,0 & 17,2 & B17 & M200 & 1,90 \\
\hline Z2030-vt & 30 & 163,3 & 16,0 & B16 & M200 & 1,76 \\
\hline Z3025-vt & 25 & 88,3 & 8,7 & B8 & M100 & 1,64 \\
\hline Z4020-vt & 20 & 36,1 & 3,5 & $\mathrm{~B} 3,5$ & M50 & 1,59 \\
\hline Z0040-vt & 40 & 386,0 & 37,9 & B30 & M400 & 2,59 \\
\hline Z1035-vt & 35 & 329,0 & 32,3 & $\mathrm{~B} 25$ & M350 & 2,37 \\
\hline Z2030-vt & 30 & 309,0 & 30,3 & $\mathrm{~B} 25$ & M350 & 2,17 \\
\hline Z3025-vt & 25 & 236,6 & 23,3 & B20 & M250 & 1,98 \\
\hline Z4020-vt & 20 & 212,2 & 20,8 & $B 15$ & $M 200$ & 1,88 \\
\hline
\end{tabular}

Note: vt - vibrating table (sample obtained on a vibrating table);

$\mathrm{vp}-$ vibropressing (industrial design).

Based on the tests of samples using ash and slag waste from Pavlodar TPP-1, it was found that there are reserves for saving cement when using ash in the case of preparing industrial samples by vibrocompression; to adjust the composition of concrete, it is required to conduct pilot tests of products under the combined action of vibration and pressing.

On the technological line «Rifey-Udar-PU-SDA» were made industrial samples of stone wall hollow composition Z4020 (table 4). Tests have shown concrete class B15. After reducing the amount of cement, tests showed the concrete class - B3, 5 (M50), which is sufficient for the construction of low-rise buildings. The same composition was used to make «Partition stone 390x120x188 mm». The strength of the stones was also obtained B3, 5 (M50). Since this strength is not required for the material of the baffles, it is possible to reduce the consumption of cement. After laboratory tests, it was decided to investigate the use of ash and slag waste from Pavlodar TPP in industrial and field tests.

Industrial and full-scale tests of the construction product «Four-hollow wall stone, type SKT-1, using ash-and-slag waste»

- Product «Wall stone four-hollow four-hollow SKSH-1 with ash»-product size: 390x188x190 $\mathrm{mm}$.

- Test object: one-story extension to the office building of the workshop on the territory of the production site of EcostroyNII-PV LLP (Figure 10).

Parameters of the object of full-scale tests: length $-3 \mathrm{~m}$, width $-2,7 \mathrm{~m}$, height $-2,5 \mathrm{~m}$, wall thickness $-190 \mathrm{~mm}$.

The object of full-scale tests was made on a strip prefabricated concrete foundation; the laying of four-hollow wall stones was carried out with a cement-sand mortar of a ratio of 1:3.

The number of products for the construction of a full-scale object: Wall stone four-hollow hollow with the use of ash-and-slag waste -300 suitable artificial stones. The building is covered with plates PK $3 \times 1,5-2$ pcs.

Location of the object of full-scale tests: Pavlodar, central industrial region.

The purpose of carrying out full-scale tests: Research of the behavior of four-hollow wall stones based on ash and slag waste in natural operation (weight, wind, rain and snow load) in a moderately aggressive environment in order to assess the suitability of EcostroyNII-PV products for further use by consumers while ensuring safety conditions and functional load on products. 


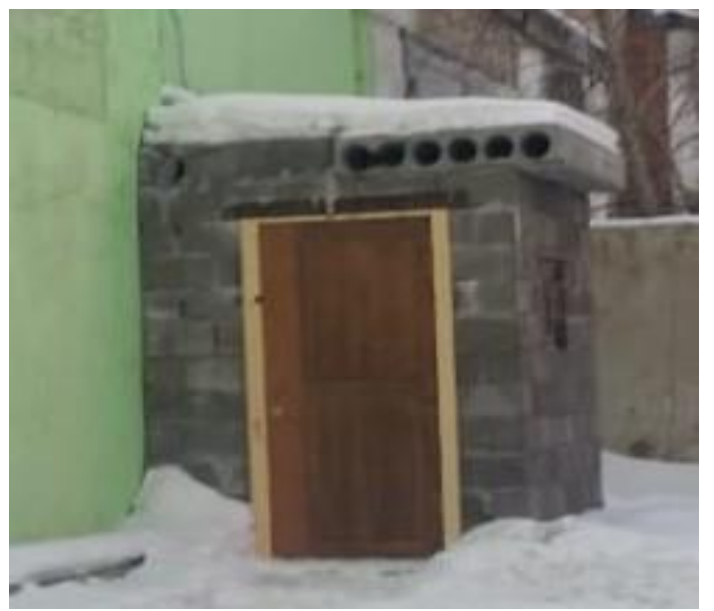

Figure 10 - Full-scale tests of the manufactured pilot-industrial batch of products «Hollow wall stone with ash-and-slag waste» in the form of construction of an extension to the production workshop of EcostroyNII-PV LLP

The composition of the raw mixes used for the manufacture of products is shown in Table 5 [19].

Table 5-Composition of raw mixes for the manufacture of hollow wall stones

\begin{tabular}{lc}
\hline \multicolumn{1}{c}{ Component name and characteristics (granulometry) } & Quantity \\
\hline $\begin{array}{l}\text { Natural sand for construction work of Pavlodar River Port JSC, size group - } \\
\text { medium, GOST 8736-2014. }\end{array}$ & $15-20 \%$ \\
\hline Ash and slag waste from TPP-1 of JSC Aluminum of Kazakhstan, GOST & $30-35 \%$ \\
25592-91. Ash and slag mixtures of thermal power plants for concrete. & \\
Technical conditions. & $35-40 \%$ \\
\hline $\begin{array}{l}\text { Screening crushing of dense rocks for construction work, LLP «Asphalt } \\
\text { concrete», deposit «Maikinskoe» GOST 31424-2010. }\end{array}$ & $9-13 \%$ \\
\hline $\begin{array}{l}\text { Portland cement Premium 450 CEM II/A-Sh 32.5N (Semey cement plant } \\
\text { production company LLP) GOST 31108-2016. }\end{array}$ & $0,16-0,2$ \\
\hline $\begin{array}{l}\text { Water-cement ratio (GOST 23732-2011 Water for concrete and mortars. } \\
\text { Specifications). }\end{array}$ & $\begin{array}{c}0,4-0,6 \% \text { by } \\
\text { Additive Solitard S3, TU 20.59.59-001-16918243-2018 LLC «Bentax», } \\
\text { Novosibirsk - 0,4-0,6 \% by weight of cement. }\end{array}$ \\
\hline
\end{tabular}

\section{Results and Discussion}

The mechanical characteristics of the products were preliminarily determined by the destructive method using a PMG 1000MG4 hydraulic press in an amount of $5 \%$ of each batch of products. Water absorption of stones was determined according to GOST 12730.3-78 «Concrete. Method for determining water absorption». 5 selected product samples were tested. The test results are shown in Table 6.

Table 6 - Test results

\begin{tabular}{lccccc}
\hline \multirow{2}{*}{ Indicator name } & \multicolumn{5}{c}{ Sample № and marking } \\
\cline { 2 - 6 } & 1 & 2 & 3 & 4 & 5 \\
\hline Weight, $\mathrm{kg}$ & 18,5 & 18,7 & 19,4 & 19,0 & 19,8 \\
\hline Ultimate strength, & $3,6 / \mathrm{B} 2,5$ & $3,3 / \mathrm{B} 2,5$ & $3,8 / \mathrm{B} 2,5$ & $3,2 / \mathrm{B} 2,5$ & $3,8 / \mathrm{B} 2,5$ \\
MPa/concrete class & 5,0 & 4,8 & 4,7 & 4,2 & 3,8 \\
\hline Water absorption, \% & 5
\end{tabular}




\section{Conclusions}

Based on the results of industrial tests, the following conclusion was obtained:

1. The produced artificial stones in their mechanical characteristics correspond to the class of concrete B2, 5;

2. During the period of observation, the object of full-scale tests within one year, the object was subjected to weight, wind, rain and snow loads;

3. The water absorption of products did not exceed $5 \%$, which corresponds to the standard indicators. Destruction of the object, cracks on the surface, delamination, chips were not observed, the object corresponds to its functional characteristics;

4. It is recommended to apply the recipe for the composition and production technology of hollow wall stones using ash and slag waste for the use of these products in low-rise construction.

\section{References}

1. Air Pollution in Kazakhstan and Its Health Risk Assessment / D. Kenessary, A. Kenessary, Z. Adilgireiuly, N. Akzholova, A. Erzhanova, A. Dosmukhametov, D. Syzdykov, A.-R. Masoud, T. Saliev // Annals of Global Health. 2019. — Vol. 85, № 1. DOI: 10.5334/aogh.2535.

2. Air Quality and Industrial Emissions in the Cities of Kazakhstan / D. Assanov, V. Zapasnyi, A. Kerimray // Atmosphere. — 2021. — Vol. 12, № 3. — C. 314. DOI: 10.3390/atmos12030314.

3. ECOLOGICAL AND TECHNOLOGYCAL ASPECTS OF ASH AND SLAG WASTES UTILIZATION / T. Aleksandrova, S. Korchevenkov // Journal of Ecological Engineering. — 2017. — Vol. 18, № 4. — C. 15-24. DOI: $10.12911 / 22998993 / 74363$.

4. Tracing the Origins of Metallurgy to the Mining Regions of Kazakhstan / A. Yermolayeva, S. Kuzminykh, Y. Dubyagina // STRATUM PLUS. — 2020. — № 2. - C. 103-116.

5. Ash and Ash-slag Waste as Multifunctional Raw Material / V.I. Kashkovsky, V.O. Yevdokymenko, D.S. Kamenskyh, T.V. Tkachenko, V.V. Vakhrin // Science and innovation. - 2017. — Vol. 13, № 4. - C. 46-55. DOI: 10.15407/scine13.04.046.

6. Composition design and performance characterization of a novel backfilling concrete derived from urban construction waste / J.X. Zhang, B. Wang, B. Song // Journal of Cleaner Production. — 2018. — Vol. 190. — C. 508-516. DOI: 10.1016/j.jclepro.2018.04.181.

7. Distribution of potentially toxic soil elements along a transect across Kazakhstan / M. Guney, A. Yagofarova, V. Yapiyev, C. Schönbach, J.R. Kim, V.J. Inglezakis // Geoderma Regional. — 2020. — Vol. 21. — C. e00281. DOI: 10.1016/j.geodrs.2020.e00281.

8. Analysis of Effect of Ground Granulated Blast Furnace Slag (GGBFS) on the Mechanical Properties of Concrete using Destructive and Non-destructive Tests / T. Yadav // JOURNAL OF MECHANICS OF CONTINUA AND MATHEMATICAL SCIENCES. — 2019. — Vol. 14, № 1. DOI: 10.26782/jmcms.2019.02.00006.

9. Durability and microstructural properties of lightweight concrete manufactured with fly ash cenosphere and sintered fly ash aggregate / S.K. Patel, R.K. Majhi, H.P. Satpathy, A.N. Nayak // Construction and Building Materials. 2019. — Vol. 226. - C. 579-590. DOI: 10.1016/j.conbuildmat.2019.07.304.

10. Evaluating engineering properties and environmental impact of pervious concrete with fly ash and slag / X. Chen, H. Wang, H. Najm, G. Venkiteela, J. Hencken // Journal of Cleaner Production. — 2019. — Vol. 237. — C. 117714. DOI: $10.1016 /$ j.jclepro.2019.117714.

11. Fly Ash Slag Geopolymer Concrete: Resistance to Sodium and Magnesium Sulfate Attack / W.G. Valencia Saavedra, D.E. Angulo, R. Mejía de Gutiérrez // Journal of Materials in Civil Engineering. — 2016. — Vol. 28, № 12. — C. 04016148. DOI: 10.1061/(ASCE)MT.1943-5533.0001618.

12. Effect of fly ash and slag on properties of normal and high strength concrete including fracture energy by wedge splitting test: Experimental and numerical investigations / A. Al-Yousuf, T. Pokharel, J. Lee, E. Gad, K. Abdouka, J. Sanjayan // Construction and Building Materials. — 2021. — Vol. 271. — C. 121553. DOI: 10.1016/j.conbuildmat.2020.121553.

13. The use of man-made waste in the production of building materials LLP "EkostroyNII-PV" / K. Aryngazin, A. Aldungarova, A. Tleulesov, P. Bykov // Construction: new technologies - new equipment. - 2018. - VOL. 12. - P. 6267.

14. Complex technological solutions for steel production and slag processing in conditions of the Pavlodar region of the Republic of Kazakhstan / A. Aldungarova, P. Bykov, K. Alibekova, V. Chaykin, A. Kasimgazinov // Bulletin de l'AcademieInternationale CONCORDE. - 2018. - C. 88-92.

15. Utilization of ferrochrome wastes such as ferrochrome ash and ferrochrome slag in concrete manufacturing / P.K. Acharya, S.K. Patro // Waste Management \& Research: The Journal for a Sustainable Circular Economy. — 2016. — Vol. 34, № 8. - C. 764-774. DOI: 10.1177/0734242X16654751. 
16. The Effect of Additional Byproducts on the Environmental Impact of the Production Stage of Concretes Containing Bottom Ash Instead of Sand / S. Pushkar // Sustainability. - 2019. - Vol. 11, № 18. - C. 5037. DOI: 10.3390/su11185037.

17. Self-consolidating concrete using recycled concrete aggregate and high volume of fly ash, and slag / Y. Khodair, B. Bommareddy // Construction and Building Materials. - 2017. - Vol. 153. - C. 307-316. DOI: 10.1016/j.conbuildmat.2017.07.063.

18. Investigation of concrete mixtures for additive construction / T.S. Rushing, G. Al-Chaar, B.A. Eick, J. Burroughs, J. Shannon, L. Barna, M. Case // Rapid Prototyping Journal. — 2017. — Vol. 23, № 1. — C. 74-80. DOI: 10.1108/RPJ09-2015-0124.

19. Concrete mix: No. of the protection document 34714; Date of application 01.08.2019, Registration No. of the application 2019/0544.1, Number of the bulletin and date of the patent publication № 46 - 11/20/2020.

\section{Information about authors:}

Aliya Aldungarova - PhD, Associate Professor, Department of Architecture and Design, Toraighyrov University, Pavlodar, Kazakhstan, liya_1479@mail.ru

Kapar Aryngazin - Candidate of Technical Sciences, Professor, Department of Architecture and Design, Toraighyrov University, Pavlodar, Kazakhstan kapar2021@gmail.com

Vladimir Larichkin - Doctor of Technical Sciences, Professor, Department of Environmental Engineering Problems, Novosibirsk State Technical University, Novosibirsk, Russia, larichkin_vv@gmail.com

Assem Abisheva - PhD Student, Department of Structural Engineering, L.N. Gumilyov Eurasian National University, Nur-Sultan, Kazakhstan, abish_assem@mail.ru

Kamilla Alibekova - PhD Student, Department of Development and Environmental Studies, Palacký University, Olomouc, Czech Republic, kamilla.alibekova01@upol.cz 